\title{
Synthesis, Characterization and Antibacterial Activity of Thorium(IV), Dioxouranium(VI), Cobalt(II), Nickel(II), Copper(II) and Zinc(II) Complexes with Picolinoyl Hydrazones
}

\author{
Abdul Ghany M. Al-Daher \\ Ahmed A. Hadi \\ Department of Chemistry/ College of Science/ University of Mosul
}

(Received $7 / 7$ / 2013 ; Accepted 23 / 9/2013)

\begin{abstract}
A series of metal complexes of $\mathrm{Th}(\mathrm{IV}), \mathrm{UO}_{2}(\mathrm{II}), \mathrm{Co}(\mathrm{II}), \mathrm{Ni}(\mathrm{II}), \mathrm{Cu}(\mathrm{II})$ and $\mathrm{Zn}(\mathrm{II})$ with 2acetyl furan picolinoyl hydrazone (AFPH) and 2-thiophen carboxaldehyde picolinoyl hydrazone (TCPH) have been synthesized. The complexes were characterized by elemental analyses (metal and $\mathrm{Cl}$ ), molar conductance, magnetic susceptibility and spectral (IR, UV-Vis) measurements.

The ligands act as neutral tridentate in metal chloride complexes of the general formula [ML( $\left.\left.\mathrm{H}_{2} \mathrm{O}\right) \mathrm{Cl}_{2}\right],[\mathrm{L}=\mathrm{AFPH}, \mathrm{M}=\mathrm{Co}(\mathrm{II}), \mathrm{Ni}(\mathrm{II}), \mathrm{Cu}(\mathrm{II}) . \mathrm{L}=\mathrm{TCPH}, \mathrm{M}=\mathrm{Co}(\mathrm{II}), \mathrm{Ni}(\mathrm{II}), \mathrm{Zn}(\mathrm{II})]$ and $\left[\mathrm{UO}_{2} \mathrm{LCl}_{2}\right](\mathrm{L}=\mathrm{AFPH}, \mathrm{TCPH})$ coordinated through carbonyl oxygen, azomethine nitrogen and pyridine nitrogen atoms. The physico-chemical studies suggest octahedral and pentagonal bipyramidal geometries respectively. On the other hand, the ligands act as monobasic tridentate coordinated through the enolic oxygen, the azomethine nitrogen and the pyridine nitrogen atoms in the deprotonated complexes of the types $[\mathrm{M}(\mathrm{L}-\mathrm{H}) \mathrm{Cl}]_{2}$, [L=AFPH, $\left.\mathrm{M}=\mathrm{Zn}(\mathrm{II}) ; \mathrm{L}=\mathrm{TCPH}, \mathrm{M}=\mathrm{Cu}(\mathrm{II})\right]$, $\left[\mathrm{Th}(\mathrm{L}-\mathrm{H})_{2} \mathrm{Cl}_{2}\right](\mathrm{L}=\mathrm{AFPH}, \mathrm{TCPH})$, and $\left[\mathrm{M}(\mathrm{L}-\mathrm{H})_{2}\right][\mathrm{L}=(\mathrm{AFPH}, \mathrm{TCPH}), \mathrm{M}=\mathrm{Co}(\mathrm{II}), \mathrm{Ni}(\mathrm{II}), \mathrm{Cu}(\mathrm{II})$, $\mathrm{Zn}(\mathrm{II}), \mathrm{UO}_{2}$ (II)] forming binuclear square pyramidal and octahedral mononuclear metal complexes. Hexagonal bipyramidal geometry proposed was for the dioxouranium(VI) complexes and square antiprismatic or dodecahedral geometries for Th(IV) complexes.
\end{abstract}

Keywords: Hydrazones, complexes, transition metals, Thorium, Uranium.

\section{تحضير وتشخيص ورلاسة مضادة للبكتربا لمقدد الثوربو (IV) وشنائي الوكسو اليورلنيو (VI)

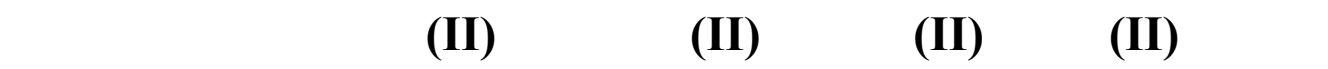

\section{الملغص}

حضر الليكانين 2 - لمتيل فيوران بيكولينويل هيدرازون (AFPH) و 2 - ث ايوفين كاربوك سي الييهاي د بيكولينوي لل

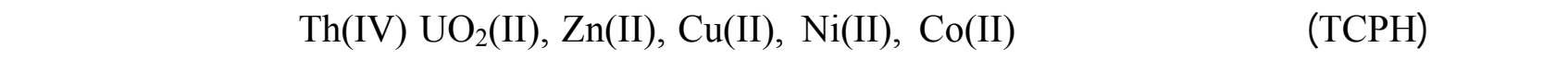
بولسطة تحاليل العناصر والطرق الطفية (IR, UV-Vis) والقيلست المغنلطيسية والتوصيلية المولارية .س الك ك لـ مـ ـن الهيدرازونين، AFPH و TCPH بوصفهما ليكانين ثلاثيي للسن NNO في جميع المعقدات المحضرة لما متع اللَ ال شحنة

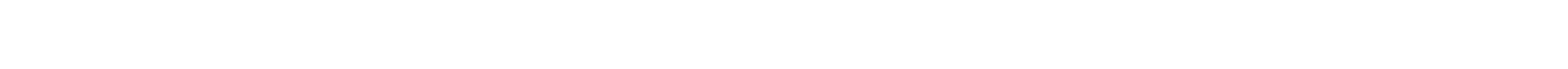
ارتبطت من خلال ذرات نتروجين مجموعة الايزوميثلن ونتروجين حلقة البرينين و أوكسجين مجموعة الكاربونيل.

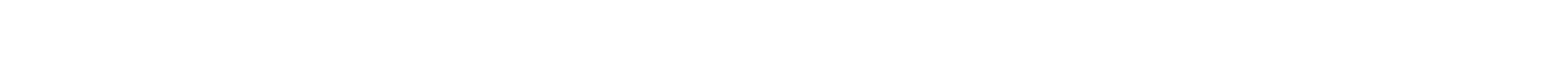

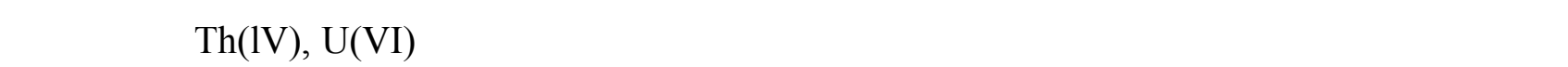

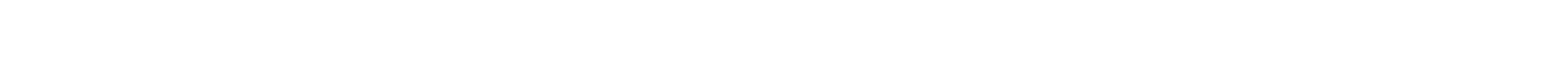




\section{INTRODUCTION}

Aroylhydrazones are an important class of ligands,coordinating through protonated/ deprotonated amide oxygen and the imine nitrogen of hydrazone moiety, very often an additional donor site $(\mathrm{N}, \mathrm{O}$, or $\mathrm{S})$ is provided by the aldehyde or ketone forming the hydrazone ligand. (Singh et al., 2011). The ligand deprotonation state depends upon condition and metal employed (Monfared et al., 2013).

Hydrazones, especially heterocyclic aroylhadrazones are multipurpose ligands having a range of biological and chemical activities (Suvarapu et al., 2012, Rollas and kucukguzel, 2007). They are well known for their metal binding ability and interesting coordination behaviour (Mondal et al., 2013), Aroylhydrazones containing heterocyclic moieties have proved to be strong chelating agents for transition metals (Singh et al., 2013, Algesan et al., 2013), lanthanides (Anwar et al., 2012), and non-transition metals, (Saadeh et al., 2012). In our laboratory we have investigated the structural diversity of heterocyclic aroylhydrazones along with their magneto-structural properties and antibacterial activities (Al-Daher and Al-Qassar, 2011; Al-Daher and Mohammed, 2011; AlDaher and Mustafa, 2013). In view of the significant role played by the heterocyclic hydrazones and their metal complexes in biological systems and in various other fields we motivated to synthesize $\mathrm{Co}(\mathrm{II}), \mathrm{Ni}(\mathrm{II}), \mathrm{Cu}(\mathrm{II}), \mathrm{Zn}(\mathrm{II}), \mathrm{UO}_{2}(\mathrm{II})$ and $\mathrm{Th}(\mathrm{IV})$ complexes with 2-thiophene carboxaldehyde and 2-acetyl furan picolinoyl hydrazone (Scheme 1) and study their physico-chemical properties, coordination behavior and antibacterial activity.

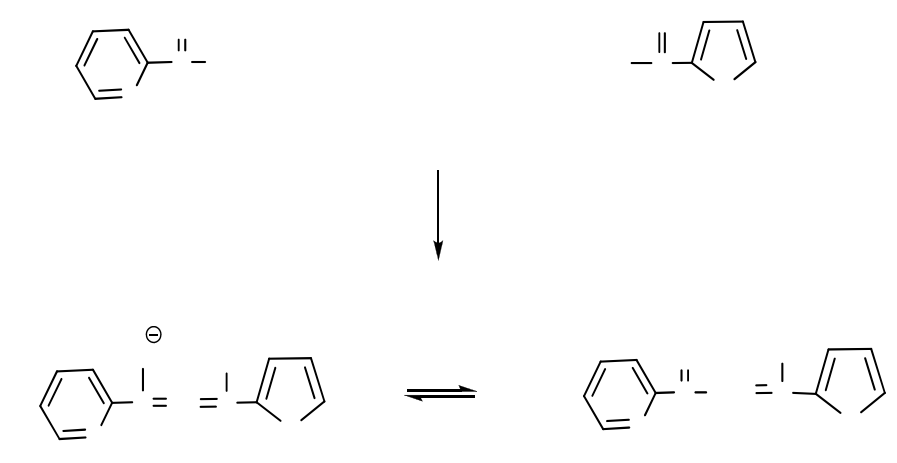

\section{Material and Measurements}

\section{EXPERIMENTAL}

All chemicals used were reagent grade from B.D.H and Fluka companies, used as supplied, except for 2-acetyl furan and 2-thiophene carboxaldehyde purified according to litrature (Perrin et al.,1980).

The IR spectra were Performed between 4000 and $400 \mathrm{~cm}^{-1}$ using $\mathrm{KBr}$ pellets on a Teson 27 Brucker FT-IR, the intensity of reported IR bands is defined as $\mathrm{s}=$ strong, $\mathrm{m}=$ medium, $\mathrm{w}=\mathrm{weak}$. Metal analyses were carried out by spectrophotometric methods [Co(II), Ni(II), Cu(II), and $\mathrm{Zn}(\mathrm{II})$ ] using Shimadzu (AA670) atomic absorption spectrophotometer and Jasco V-630 to determine $\mathrm{Th}(\mathrm{IV})$ and U(VI) colourimetrically by the reagents thoron and arsinszo(III) respectively (Marczenko and Balcerzak, 2000). Ni(II) and $\mathrm{Zn}(\mathrm{II})$ are also determined by complexometric titration against standard EDTA solution, Chloride was determined volumetrically by Mhor's method (Vogel, 1989).

Melting points were obtained on Electrothermal 9300 melting poi@ apparatus in open capillaries. Electoronic absorption spectra $(190-1100 \mathrm{~nm})$ were recorded in $\mathrm{QMF}^{-2} \mathrm{M}$ solutions on Shimadzu U.V-1650 PC spectrophotometer at room temperature using licm cell. Molar conductance was measured at room temperature for $10^{-3} \mathrm{M}$ solutions inNethanol and in DMF using 
PMC3 Jeneway conductivity meter. Magnetic susceptibility measurements of the complexes were performed on Bruker BM6 instrument at ambient temperature.

Preparation of the ligands

a. Preparation of 2-Picolinic acid hydrazide

This was prepared by the reaction of ethyl picolinate and hydrazine hydrate as reported by (Zareef et al., 2006) (m.p144 - $145^{\circ} \mathrm{C}$ ).

\section{b. Preparation of the ligand 2-Acetyl Furan Picolinoyl hydrazon (AFPH):-}

This was prepared according to literature method (Abd El-Motaleb et al., 2005). To a solution of picolinic acid hydrazide $(6.85 \mathrm{~g}, 0.05$ mole $)$ in absolute ethanol $(20 \mathrm{~mL})$ was added a solution of 2-acetyl furan $(5.5 \mathrm{~g}, 0.05$ mole) in absolute ethanol $(20 \mathrm{~mL})$. The reaction mixture was stirred and boiled under reflux for $3 \mathrm{hrs}$.On cooling in an ice-bath, the white crystalline solid that precipitated was separated by filtration, washed with cold ethanol $(5 \mathrm{~mL})$ then with ether $(5 \mathrm{~mL})$ and dried in an oven at $\left(80-90^{\circ} \mathrm{C}\right)$ m.p $164^{\circ} \mathrm{C}$.

\section{c. Preparation of the ligand 2-Thiophen carboxaldehyde Picolinoyl hydrazon (TCPH):-}

This was prepared by the same procedure reported in (b) above using $(6.85 \mathrm{~g}, 0.05$ mole) picolinic acid hydrazide and (5.5g, 0.05mole)2-thiophen carboxaldehyde. The hydrazone separated on cooling in an ice- bath as light yellowish crystalline product was filtered, washed and dried as above (m.p $\left.190^{\circ} \mathrm{C}\right)$.

\section{Preparation of the Metal Complexes}

\section{a. Preparation of metal chloride Complexes}

The appropriate metal chloride (0.001 mole) [0.238g, $\mathrm{CoCl}_{2} \cdot 6 \mathrm{H}_{2} \mathrm{O} ; 0.238 \mathrm{~g}, \mathrm{NiCl}_{2} .6 \mathrm{H}_{2} \mathrm{O}$; $\left.0.171 \mathrm{~g}, \mathrm{CuCl}_{2} .2 \mathrm{H}_{2} \mathrm{O} ; 0.136 \mathrm{~g}, \mathrm{ZnCl}_{2} ; 0.377 \mathrm{~g}, \mathrm{UO}_{2} \mathrm{Cl}_{2} .2 \mathrm{H}_{2} \mathrm{O}\right]$ in $(10 \mathrm{~mL})$ absolute ethanol was heated under reflux with constant stirring with $(0.229 \mathrm{~g}, 0.001 \mathrm{~mole})$ of the ligand (AFPH ) or $(0.231 \mathrm{~g}, 0.001 \mathrm{~mole})$ of the ligand $(\mathrm{TCPH})$. in $(10 \mathrm{~mL})$ absolute ethanol for $2 \mathrm{hrs}$. The solid complexes formed were then separated by filtration, washed with ethanol $(5 \mathrm{~mL})$ and finally dried in an oven at $\left(70-80^{\circ} \mathrm{C}\right)$ and kept in disecator. In case of thorium(IV) complexes $(0.001 \mathrm{~mole})$ $\left[0.464 \mathrm{~g}, \mathrm{ThCl}_{4} .5 \mathrm{H}_{2} \mathrm{O}\right]$ and $(0.458 \mathrm{~g}, 0.002$ mole $)$ of the ligand $(\mathrm{AFPH})$ or $(0.462 \mathrm{~g}, 0.002 \mathrm{~mole})$ of the ligand (TCPH) were used in absolute ethanol respectively.

\section{b. Preparation of the deprotonated bis Complexes}

To stirred hot ethanolic solution $(20 \mathrm{~mL})$ of the appropriate metal acetate $(0.001$ mole $)$ $\left[0.249 \mathrm{~g}, \mathrm{Co}\left(\mathrm{CH}_{3} \mathrm{COO}\right)_{2} .4 \mathrm{H}_{2} \mathrm{O} ; 0.249 \mathrm{~g}, \mathrm{Ni}\left(\mathrm{CH}_{3} \mathrm{COO}\right)_{2} .4 \mathrm{H}_{2} \mathrm{O} ; 0.199 \mathrm{~g}, \mathrm{Cu}\left(\mathrm{CH}_{3} \mathrm{COO}\right)_{2} . \mathrm{H}_{2} \mathrm{O} ; 0.219 \mathrm{~g}\right.$, $\left.\mathrm{Zn}\left(\mathrm{CH}_{3} \mathrm{COO}\right)_{2} .2 \mathrm{H}_{2} \mathrm{O} ; 0.424 \mathrm{~g} \mathrm{UO}{ }_{2}\left(\mathrm{CH}_{3} \mathrm{COO}\right)_{2} .2 \mathrm{H}_{2} \mathrm{O}\right]$ was added $(0.458 \mathrm{~g}, 0.002$ mole $)$ of the ligand $(\mathrm{AFPH})$ or $(0.462 \mathrm{~g}, 0.002$ mole $)$ of the ligand $(\mathrm{TCPH})$ in absolute ethanol $(10 \mathrm{~mL})$. The reaction mixture was then heated under reflux with constant stirring for 3 hrs upon which the solid complexes were separated, filtered off and washed with ethanol $(5 \mathrm{~mL})$ and dried as above.

\section{Antibacterial activity}

Antibacterial activity was evaluated using agar diffusion method (Kethcum, 1988). Grampositive bacteria Staphylococcus aureus and Gram-nagtive bacteria Klebsiella pneumoniae were cultivated in nutrient agar on petri dishes. The test solution was prepared by dissolving (10 $\mathrm{mg}) \mathrm{of}$ the tested substances in DMSO $(1 \mathrm{~mL}) .6 \mathrm{~mm}$ diameter filter discs were socked in the tested solutions. After $24 \mathrm{~h}$ cultivation at $37^{\circ} \mathrm{C}$, the diameters of zones of inhibition were determined. DMSO was inactive under applied conditions.

\section{RESULTS AND DISCUSSION}

It appears from the analytical data Table (1). That reaction between metal chlorides and the ligands AFPH or TCPH occur in 1:1 (M:L) molar ratio, and the reactions of metal acetates with the same ligands take place in (1:2) molar ratio, forming bis-deprotonated complexes in witch, the ligands enolize and deprotonate during complexation. The complexes are colored powdery solids. 
They are sparingly soluble in common organic solvent, ethanol, methanol, DMF and DMSO but are in soluble in chloroform, acetone and diethylether. Most of the complexes melt or melt with decomposition at relatively low temperatures which may indicate the non-polymeric nature of the complexes. The low molar conductance values at room temperature of $10^{-3} \mathrm{M}$ solution in ethanol (2.08-18.32 $\left.\mathrm{ohm}^{-1} \mathrm{~mol}^{-1} \mathrm{~cm}^{2}\right)$ and in DMF (1.56-29.48 $\left.\mathrm{ohm}^{-1} \mathrm{~mol}^{-1} \mathrm{~cm}^{2}\right)$ indicate that they are nonelectrolytes (Geary, 1971).

Table 1: physical properties and analysis data of the ligands and their complexes

\begin{tabular}{|c|c|c|c|c|c|c|c|c|}
\hline \multirow{3}{*}{$\begin{array}{c}\begin{array}{c}\text { Complex } \\
\text { No. }\end{array} \\
\text { L1 } \\
\end{array}$} & \multirow[t]{2}{*}{ Formula } & \multirow[t]{2}{*}{ Color } & \multirow[t]{2}{*}{$\mathbf{m} . \mathbf{P C}^{\mathbf{0}}$} & \multirow{2}{*}{$\begin{array}{c}\text { Yield } \\
\%\end{array}$} & \multicolumn{2}{|c|}{$\Omega o h m^{-1} \mathrm{Cm}^{2} \mathrm{~mol}^{-1}$} & M\% & $\mathrm{Cl} \%$ \\
\hline & & & & & Ethanol & DMF & \multicolumn{2}{|c|}{ Found/(Calculated) } \\
\hline & $\operatorname{AFPH}\left(\mathrm{C}_{12} \mathrm{H}_{11} \mathrm{~N}_{3} \mathrm{O}_{2}\right)$ & White & 163 & 86 & & & & \\
\hline 1 & {$\left[\mathrm{Co}(\mathrm{AFPH})\left(\mathrm{H}_{2} \mathrm{O}\right) \mathrm{Cl}_{2}\right]$} & Brown & $280 \mathrm{~d}$ & 60 & 2.08 & 15.09 & $\begin{array}{c}15.20 \\
(15.63)\end{array}$ & $\begin{array}{c}19.36 \\
(18.83)\end{array}$ \\
\hline 2 & {$\left[\mathrm{Ni}(\mathrm{AFPH})\left(\mathrm{H}_{2} \mathrm{O}\right) \mathrm{Cl}_{2}\right]$} & Green & 232 & 71 & 8.88 & 12.93 & $\begin{array}{l}15.82 \\
(15.58)\end{array}$ & $\begin{array}{c}18.31 \\
(18.84)\end{array}$ \\
\hline 3 & {$\left[\mathrm{Cu}(\mathrm{AFPH})\left(\mathrm{H}_{2} \mathrm{O}\right) \mathrm{Cl}_{2}\right]$} & Green & 236 & 67 & 10.12 & 19.59 & $\begin{array}{c}17.04 \\
(16.64)\end{array}$ & $\begin{array}{c}18.46 \\
(18.61)\end{array}$ \\
\hline 4 & {$[\mathrm{Zn}(\mathrm{AFPH}-\mathrm{H}) \mathrm{Cl}]_{2}$} & Yellow & 269 & 74 & 14.34 & 11.07 & $\begin{array}{c}19.32 \\
(19.87)\end{array}$ & $\begin{array}{c}10.24 \\
(10.79)\end{array}$ \\
\hline 5 & {$\left[\mathrm{Th}(\mathrm{AFPH}-\mathrm{H})_{2} \mathrm{Cl}_{2}\right]$} & $\begin{array}{l}\text { Yellowish } \\
\text { Orang }\end{array}$ & $300 d$ & 57 & 13.40 & 20.29 & $\begin{array}{c}31.10 \\
(30.56)\end{array}$ & $\begin{array}{c}9.02 \\
(9.35)\end{array}$ \\
\hline 6 & {$\left[\mathrm{UO}_{2}(\mathrm{AFPH}) \mathrm{Cl}_{2}\right]$} & $\begin{array}{c}\text { Pale } \\
\text { yellow }\end{array}$ & 275 & 85 & 10.70 & 21.99 & $\begin{array}{c}42.16 \\
(41.75) \\
\end{array}$ & $\begin{array}{c}12.15 \\
(12.45) \\
\end{array}$ \\
\hline 7 & {$\left[\mathrm{Co}(\mathrm{AFPH}-\mathrm{H})_{2}\right]$} & $\begin{array}{c}\text { Pale } \\
\text { brawn }\end{array}$ & 100 & 82 & 7.33 & 4.94 & $\begin{array}{c}11.85 \\
(11.44)\end{array}$ & \\
\hline 8 & {$\left[\mathrm{Ni}(\mathrm{AFPH}-\mathrm{H})_{2}\right]$} & Pale green & 138 & 75 & 9.36 & 7.44 & $\begin{array}{c}11.06 \\
(11.40) \\
\end{array}$ & \\
\hline 9 & {$\left[\mathrm{Cu}(\mathrm{AFPH}-\mathrm{H})_{2}\right]$} & $\begin{array}{l}\text { Dark } \\
\text { green }\end{array}$ & 150 & 68 & 11.93 & 6.07 & $\begin{array}{c}11.81 \\
(12.22)\end{array}$ & \\
\hline 10 & {$\left[\mathrm{Zn}(\mathrm{AFPH}-\mathrm{H})_{2}\right]$} & Yellow & 110 & 68 & 7.35 & 4.52 & $\begin{array}{c}12.81 \\
(12.53) \\
\end{array}$ & \\
\hline 11 & {$\left[\mathrm{UO}_{2}(\mathrm{AFPH}-\mathrm{H})_{2}\right]$} & Yellow & $295 d$ & 72 & 7.65 & 9.55 & $\begin{array}{c}32.36 \\
(32.78) \\
\end{array}$ & \\
\hline $\mathrm{L} 2$ & $\mathrm{TCPH}\left(\mathrm{C}_{11} \mathrm{H}_{9} \mathrm{~N}_{3} \mathrm{OS}\right)$ & $\begin{array}{c}\text { Yellowish } \\
\text { Orang }\end{array}$ & 192 & 75 & & & & \\
\hline 12 & {$\left[\mathrm{Co}(\mathrm{TCPH})\left(\mathrm{H}_{2} \mathrm{O}\right) \mathrm{Cl}_{2}\right]$} & Pink & 290 & 75 & 13.16 & 21.98 & $\begin{array}{c}16.02 \\
(15.55)\end{array}$ & $\begin{array}{c}18.25 \\
(18.73)\end{array}$ \\
\hline 13 & {$\left[\mathrm{Ni}(\mathrm{TCPH})\left(\mathrm{H}_{2} \mathrm{O}\right) \mathrm{Cl}_{2}\right]$} & Green & 320 & 76 & 15.50 & 17.28 & $\begin{array}{c}15.96 \\
(15.50)\end{array}$ & $\begin{array}{c}18.29 \\
(18.74)\end{array}$ \\
\hline 14 & {$[\mathrm{Cu}(\mathrm{TCPH}-\mathrm{H}) \mathrm{Cl}]_{2}$} & Pale green & 221 & 72 & 18.14 & 29.48 & $\begin{array}{c}18.87 \\
(19.30)\end{array}$ & $\begin{array}{c}10.23 \\
(10.79)\end{array}$ \\
\hline 15 & {$\left[\mathrm{Zn}(\mathrm{TCPH})\left(\mathrm{H}_{2} \mathrm{O}\right) \mathrm{Cl}_{2}\right]$} & Yellow & 203 & 63 & 16.21 & 11.26 & $\begin{array}{c}16.65 \\
(16.96) \\
\end{array}$ & $\begin{array}{c}19.04 \\
(18.42) \\
\end{array}$ \\
\hline 16 & {$\left[\mathrm{UO}_{2}(\mathrm{TCPH}) \mathrm{Cl}_{2}\right]$} & Yellow & $280 d$ & 87 & 17.56 & 20.18 & $\begin{array}{c}41.25 \\
(41.60)\end{array}$ & $\begin{array}{c}11.83 \\
(12.41)\end{array}$ \\
\hline 17 & {$\left[\mathrm{Th}(\mathrm{TCPH}-\mathrm{H})_{2} \mathrm{Cl}_{2}\right]$} & Yellow & $305 d$ & 85 & 18.32 & 24.78 & $\begin{array}{c}30.02 \\
(30.40) \\
\end{array}$ & $\begin{array}{c}9.59 \\
(9.30) \\
\end{array}$ \\
\hline 18 & {$\left[\mathrm{Co}(\mathrm{TCPH}-\mathrm{H})_{2}\right]$} & Brown & $300 d$ & 80 & 2.44 & 7.21 & $\begin{array}{c}11.05 \\
(11.35) \\
\end{array}$ & \\
\hline 19 & {$\left[\mathrm{Ni}(\mathrm{TCPH}-\mathrm{H})_{2}\right]$} & Pale green & 112 & 80 & 3.72 & 7.65 & $\begin{array}{c}11.78 \\
(11.31)\end{array}$ & \\
\hline 20 & {$\left[\mathrm{Cu}(\mathrm{TCPH}-\mathrm{H})_{2}\right]$} & Pale green & $240 d$ & 66 & 3.42 & 1.56 & $\begin{array}{c}12.64 \\
(12.12) \\
\end{array}$ & \\
\hline 21 & {$\left[\mathrm{Zn}(\mathrm{TCPH}-\mathrm{H})_{2}\right]$} & White & 328 & 78 & 3.82 & 7.75 & $\begin{array}{c}12.12 \\
(12.44) \\
\end{array}$ & \\
\hline 22 & {$\left[\mathrm{UO}_{2}(\mathrm{TCPH}-\mathrm{H})_{2}\right]$} & $\begin{array}{c}\text { Yellowish } \\
\text { Orang }\end{array}$ & $240 \mathrm{~d}$ & 73 & 10.20 & 5.71 & $\begin{array}{c}32.22 \\
(32.60) \\
\end{array}$ & \\
\hline
\end{tabular}




\section{Infrared spectra}

The IR spectra of the free ligands and their metal complexes were compared to get information about the coordination behavior of the ligands with the metals (Table 3 ).

In the IR spectra of the ligands, the vibration bands $v_{(\mathrm{N}-\mathrm{H})}, v_{(\mathrm{C}=\mathrm{O})}, v_{(\mathrm{C}=\mathrm{N})}, v_{(\mathrm{N}-\mathrm{N})}$ and $\delta$ py were observed at 3325, 1685, 1618, 997 and $621 \mathrm{~cm}^{-1}$ respectively for the ligand AFPH and at 3234 , $1676,1622,997$ and $619 \mathrm{~cm}^{-1}$ respectively for the ligand TCPH.

In the IR spectra of the metal chloride complexes $(1,2,3,6,12,13,15,16)$ the bands of $v_{(\mathrm{N}-\mathrm{H})}$ is either unchanged or shifted to higher frequencies indicating non-involvement in coordination. The band due to $v_{(\mathrm{c}=0)}$ is shifted to lower frequencies in these complexes by $36-55 \mathrm{~cm}^{-1}$ indicating coordination through the oxgen atom of the carbonyl group (i.e the ligands are coordinated in the keto-form). The bands of $v_{(\mathrm{N}-\mathrm{H})}$ and $v_{(\mathrm{C}=\mathrm{O})}$ were absent in the spectra of the metal chloride complexes $(4,5,14,17)$ suggesting coordination via enol- form, by the deprotonation of the N-H proton, during the complexation process similar observation were noticed in the IR spectra of the deprotonated bis-complexes $(7-11,18-22)$ in which the $v_{(\mathrm{N}-\mathrm{H})}$ and $v_{(\mathrm{C}=\mathrm{O})}$ are not observed due to enolization of carbonyl group of the ligands due to complex formation. The appearance of anew $v_{(\mathrm{c}-\mathrm{o})}$ band in these complexes at the region 1286-1302 $\mathrm{cm}^{-1}$ suggest bonding of the ligands to the metal ions through deprotonated (C-O) group (Abu Affan et al., 2009).

The stretching vibrations of azomethine group $v_{(\mathrm{C}=\mathrm{N})}$ are shifted to lower frequencies in all the complexes spectra and this proves that nitrogen atom of azomethine group is involved in complexation, coordination of nitrogen to the metal atom reduces the electron density in the azomethine causing a shift in the $v_{(\mathrm{C}=\mathrm{N})}$ band (Shrarma et al., 2006). The spectra of the deprotonated complexes show two bands due to $v_{(\mathrm{C}=\mathrm{N})}$ in the ranges $1608-1581 \mathrm{~cm}^{-1}$ and $1579-1541 \mathrm{~cm}^{-1}$, the first one is due to the enolization of the ligands $v_{(-\mathrm{O}-\mathrm{C}=\mathrm{N})}$ whereas the second one result is due to down shift of $v_{(\mathrm{C}=\mathrm{N})}$ on coordination with metal (Singh and Sing, 2013). The $v_{(\mathrm{N}-\mathrm{N})}$ observed at $997 \mathrm{~cm}^{-1}$ in the spectra of AFPH and TCPH, shifts to higher frequencies by $12-27 \mathrm{~cm}^{-1}$ in their complexes. This indicates the coordination of one of the nitrogen atom of N-N group with metal (Singh et al., 2013). This phenomenone is owing to the diminution of the lone pair electrons repulsion which come from the two adjacent nitrogen atoms, by sharing the electrons out to the metal ion (Abu Affan et al., 2009).

The pyridine in-plane deformation mode $\delta\left(\right.$ py) at the region $619-621 \mathrm{~cm}^{-1}$ of the ligands spectra shifts to higher frequencies $625-669 \mathrm{~cm}^{-1}$ in spectra of the complexes the suggesting the coordination of the heterocyclic nitrogen atom (Despaigen et al., 2009).

The metal complexes also show non-ligand bands in the ranges $507-573 \mathrm{~cm}^{-1}$ and $476-420 \mathrm{~cm}^{-1}$ which are tentatively assigned to $v_{\mathrm{M}-\mathrm{O}}, v_{\mathrm{M}-\mathrm{N}}$ respectively.

Many workers (Halli and Malipatil, 2011) have reported $v_{\mathrm{C}-\mathrm{O}-\mathrm{C}}$ stretching vibrations of furan ring in the region $1020-1250 \mathrm{~cm}^{-1}$ in the present case the band at $1090 \mathrm{~cm}^{-1}$ in the spectrum of the AFPH ligand assigned as $v_{(\mathrm{C}-\mathrm{O}-\mathrm{C})}$ stretching, witch almost remain unaltered in the metal complexes Table (2) indicating non-participation of the furan ring oxygen atom in bonding with metal.

The medium intensity band observed at $850 \mathrm{~cm}^{-1}$ in the spectrum of the ligand TCPH due to $v_{\text {(C-S-C) }}$ of thiophene ring is also unaffected by coordination and remains almost at the same position in the metal complexes, which indicates the non-involvement of thiophene sulfur atom in bonding (Singh et al., 2011; Abu Affan et al., 2009).

The spectra of the complexes $(1,2,3,12,13,15)$ exhibit a broad band centered around $3400 \mathrm{~cm}^{-1}$ due to the symmetric and asymmetric stretching modes of coordinated water molecule. The H-O-H bending modes occur in the $1630-1610 \mathrm{~cm}^{-1}$ range. Weak bands in the 940-900, $770-750$ and $660-640 \mathrm{~cm}^{-1}$ ranges represent the wagging, twisting and rocking modes of coordinated water (Singh, 2008). 
The additional band appearing at the region $899-930 \mathrm{~cm}^{-1}$ in the spectra of uranyl complexes $(6,11,16,22)$ is attributed to the symmetric stretching vibration of $\mathrm{O}=\mathrm{U}=\mathrm{O}$ group. The absence of the $v_{1}$ mode of the $\mathrm{O}=\mathrm{U}=\mathrm{O}$ indicating the linearity of the $\mathrm{UO}_{2}(\mathrm{II})$ species is maintained in the complexes (Gandi et al., 2001).

On the basis of the above observations, it was found that the ligands AFPH and TCPH are coordinated in the keto-form in the metal chloride complexes $(1,2,3,6,12,13,15,16)$ acting as neutral tridentate ligands through the carbonyl oxegen, imine nitrogen and pyridine nitrogen atoms. In the deprotonated complexes $(4,5,7,8,9,10,11,14,17,18,19,20,21,22)$ AFPH and TCPH coordinated to the metals in the enolate from acting as monobasic tridentate coordinating through the enolic oxygen in addition to imine and pyridine nitrogen atoms (Fig. 1).

Table 2:Characteristic IR spectral bands of the ligands and their complexes

\begin{tabular}{|c|c|c|c|c|c|c|c|c|c|c|}
\hline $\begin{array}{c}\text { Complex } \\
\text { No. }\end{array}$ & $v_{\mathrm{NH}}$ & $\mathbf{v}_{\mathrm{C}=\mathbf{O}}$ & $\mathbf{v}_{\mathrm{C}=\mathbf{N}}$ & $v_{N-N}$ & $v_{\mathrm{C}-\mathrm{O}}$ & $\begin{array}{c}\delta P y \\
\text { inplane }\end{array}$ & $\mathbf{v}_{\mathrm{C}-\mathrm{O}-\mathrm{C}}$ & $v_{\text {C-S-C }}$ & $\mathbf{v}_{\mathrm{M}-\mathrm{O}}$ & $\mathbf{v}_{\mathrm{M}-\mathrm{N}}$ \\
\hline L1(AFPH) & $3325 \mathrm{~m}$ & $1685 \mathrm{~s}$ & $1618 \mathrm{~m}$ & $997 \mathrm{~m}$ & ---- & $621 \mathrm{sh}$ & $1090 \mathrm{~m}$ & ---- & ------ & ----- \\
\hline 1 & $3384 \mathrm{~m}$ & $1635 \mathrm{~s}$ & $1597 \mathrm{~s}$ & $1020 \mathrm{~m}$ & ---- & $660 \mathrm{~m}$ & $1111 \mathrm{~m}$ & ---- & $567 \mathrm{~m}$ & $428 \mathrm{w}$ \\
\hline 2 & $3392 \mathrm{~m}$ & $1638 \mathrm{~s}$ & $1593 \mathrm{~s}$ & $1020 \mathrm{~m}$ & ---- & $656 \mathrm{~m}$ & $1107 \mathrm{~m}$ & $\begin{array}{l}--- \\
\end{array}$ & $548 \mathrm{~m}$ & $430 w$ \\
\hline 3 & $3380 \mathrm{~m}$ & $1649 \mathrm{~s}$ & $1601 \mathrm{~s}$ & $1020 \mathrm{~m}$ & ---- & $648 \mathrm{~m}$ & $1102 \mathrm{~m}$ & ---- & $513 \mathrm{~m}$ & $461 w$ \\
\hline 4 & ---- & ----- & $\begin{array}{l}1597 \mathrm{~s} \\
1552 \mathrm{~s} \\
\end{array}$ & $1018 \mathrm{~s}$ & $1298 \mathrm{~m}$ & $625 w$ & $1111 \mathrm{~m}$ & ---- & $565 \mathrm{~m}$ & $463 w$ \\
\hline 5 & ---- & ----- & $\begin{array}{l}1601 \mathrm{~m} \\
1566 \mathrm{~m} \\
\end{array}$ & $1012 w$ & $1302 \mathrm{~m}$ & $656 \mathrm{~m}$ & $1093 m$ & ---- & $515 \mathrm{~m}$ & $430 w$ \\
\hline 6 & $3328 \mathrm{~m}$ & $1630 \mathrm{~s}$ & $1603 \mathrm{~m}$ & $1009 \mathrm{~m}$ & ------ & 634sh & $1101 \mathrm{~m}$ & ---- & $561 \mathrm{~m}$ & $430 w$ \\
\hline 7 & ---- & ---- & $\begin{array}{c}1591 \mathrm{~m} \\
1550 \mathrm{~s}\end{array}$ & $1018 \mathrm{~m}$ & $1294 m$ & $669 \mathrm{~m}$ & $1101 \mathrm{~m}$ & ---- & $513 \mathrm{~m}$ & $465 w$ \\
\hline 8 & ---- & ---- & $\begin{array}{c}1585 \mathrm{~s} \\
1552 \mathrm{~m} \\
\end{array}$ & $1020 \mathrm{~m}$ & $1286 \mathrm{~m}$ & $644 \mathrm{~m}$ & $1101 \mathrm{~m}$ & ---- & $538 \mathrm{~m}$ & $476 w$ \\
\hline 9 & ---- & ---- & $\begin{array}{l}1597 \mathrm{~s} \\
1579 \mathrm{~s}\end{array}$ & $1018 \mathrm{~m}$ & $1294 m$ & $650 \mathrm{sh}$ & $1099 \mathrm{~m}$ & ---- & $573 \mathrm{~m}$ & $474 w$ \\
\hline 10 & ---- & ---- & $\begin{array}{l}1604 \mathrm{~s} \\
1541 \mathrm{~s} \\
\end{array}$ & $1024 \mathrm{~m}$ & $1296 \mathrm{~s}$ & 630sh & $1109 m$ & ---- & $563 \mathrm{~m}$ & $420 w$ \\
\hline 11 & ---- & ---- & $\begin{array}{c}1608 \mathrm{ml} \\
566 \mathrm{~s}\end{array}$ & $1024 \mathrm{~m}$ & $1296 \mathrm{~s}$ & $642 \mathrm{~m}$ & $1103 \mathrm{~m}$ & ---- & $528 \mathrm{~m}$ & $420 w$ \\
\hline L2(TCPH) & $3234 \mathrm{~m}$ & $1676 \mathrm{~s}$ & $1622 \mathrm{~m}$ & $997 \mathrm{~s}$ & ------ & $619 \mathrm{~m}$ & --- & $850 \mathrm{~m}$ & ------ & ------ \\
\hline 12 & $3248 s$ & $1637 \mathrm{~s}$ & $1601 \mathrm{~s}$ & $1014 \mathrm{~m}$ & ------ & 640sh & ---- & $856 \mathrm{~m}$ & $513 \mathrm{~m}$ & $428 w$ \\
\hline 13 & $3248 \mathrm{~m}$ & $1637 \mathrm{~s}$ & $1601 \mathrm{~s}$ & $1020 \mathrm{~m}$ & ------ & $650 \mathrm{~m}$ & ---- & $854 \mathrm{~m}$ & $507 \mathrm{~m}$ & $426 w$ \\
\hline 14 & ----- & ----- & $\begin{array}{l}1597 \mathrm{~s} \\
1564 \mathrm{~s} \\
\end{array}$ & $1018 \mathrm{~m}$ & $1294 m$ & 650sh & ---- & $860 \mathrm{~m}$ & $530 \mathrm{~m}$ & $438 w$ \\
\hline 15 & $3263 \mathrm{~m}$ & $1635 \mathrm{vs}$ & $1595 \mathrm{~s}$ & $1020 \mathrm{~m}$ & ------ & $642 \mathrm{~s}$ & ---- & $858 \mathrm{~m}$ & $519 \mathrm{~m}$ & $430 w$ \\
\hline 16 & $3260 \mathrm{~m}$ & $1637 \mathrm{~m}$ & $1589 \mathrm{~s}$ & $1011 \mathrm{~m}$ & ------ & $634 \mathrm{~m}$ & ---- & $854 w$ & $528 \mathrm{~m}$ & $428 w$ \\
\hline 17 & ---- & ---- & $\begin{array}{c}1595 \mathrm{~s} \\
1562 \mathrm{~m} \\
\end{array}$ & $1011 \mathrm{~m}$ & $1298 \mathrm{~m}$ & $636 \mathrm{~m}$ & ---- & $862 \mathrm{~m}$ & $538 \mathrm{~m}$ & $430 w$ \\
\hline 18 & ---- & ---- & $\begin{array}{l}1601 \mathrm{~s} \\
1547 \mathrm{~s} \\
\end{array}$ & $1009 \mathrm{~m}$ & $1298 \mathrm{~m}$ & $640 w$ & ---- & $860 w$ & $507 \mathrm{~m}$ & $428 w$ \\
\hline 19 & ---- & ---- & $\begin{array}{c}1604 \mathrm{~s} \\
1570 \mathrm{~m} \\
\end{array}$ & $1011 \mathrm{~m}$ & $1298 \mathrm{~m}$ & $669 \mathrm{~m}$ & ---- & $860 w$ & $560 \mathrm{~m}$ & $420 w$ \\
\hline 20 & ---- & ---- & $\begin{array}{c}1581 \mathrm{~s} \\
1560 \mathrm{~m} \\
\end{array}$ & $1018 \mathrm{~m}$ & $1288 \mathrm{~s}$ & $656 \mathrm{~m}$ & ---- & $865 \mathrm{~m}$ & $534 \mathrm{~m}$ & $428 w$ \\
\hline 21 & ---- & ---- & $\begin{array}{c}1604 \mathrm{~m} \\
1541 \mathrm{~s} \\
\end{array}$ & $1016 \mathrm{~m}$ & $1296 \mathrm{~m}$ & $654 \mathrm{~m}$ & ---- & $856 \mathrm{w}$ & $536 \mathrm{~m}$ & $440 w$ \\
\hline 22 & ---- & ---- & $\begin{array}{c}1595 \mathrm{~s} \\
1556 \mathrm{~m}\end{array}$ & $1018 \mathrm{~m}$ & $1294 \mathrm{~s}$ & 638sh & ---- & $856 \mathrm{~m}$ & $523 \mathrm{~m}$ & $426 \mathrm{w}$ \\
\hline
\end{tabular}




\section{Electronic Spectra and Magnetic moments}

The electronic spectra of ligands and their metal complexes in the rang 190-1100nm,were carried out in DMF. Table (3) shows the electronic spectral bands and magnetic moments of the prepared complexes.

The spectra of the ligands in DMF solution exhibit two main absorption bands at 37593-33112 $\mathrm{cm}^{-1}$ and 32679-29940 $\mathrm{cm}^{-1}$. The first band probably is due to $\pi \rightarrow \pi^{*}$ transition of the chromophore $(-\mathrm{C}=\mathrm{N}-\mathrm{NH}-\mathrm{CO}-)$, and the second band might be attributed to the $\mathrm{n} \rightarrow \pi^{*}$ transitions resulting from nitrogen, oxygen and sulfur atoms. In the spectra of the complexes, the shift of the ligand transitions to a longer wavelength (red shift) is ascribed to the ligand complexation with metal ions. The new intense band observed in the spectra of all complexes at the region 28901-24752 $\mathrm{cm}^{-1}$ may be associated with the charge transfer transitions (LMCT).

The magnetic moment values of Co(II) complexes $(1,7,12,18)$ are in the range $4.81-5.05 \mathrm{~B} . \mathrm{M}$, which are fairly close to the values reported for three unpaired electrons in an octahedral environment (Singh et al., 2013). These complexes exhibit three bands in their spectra at the regions $19230-18181 \mathrm{~cm}^{-1}, 16722-14836 \mathrm{~cm}^{-1}$ and $10526-9803 \mathrm{~cm}^{-1}$ indicating an octahedral geometry around the metal ion. These transitions are assigned as ${ }^{4} \mathrm{~T}_{1 \mathrm{~g}} \rightarrow{ }^{4} \mathrm{~T}_{1 \mathrm{~g}}(\mathrm{P})\left(\mathbf{v}_{3}\right),{ }^{4} \mathrm{~T}_{1 \mathrm{~g}} \rightarrow{ }^{4} \mathrm{~A}_{2 \mathrm{~g}}(\mathrm{~F})\left(\mathbf{v}_{2}\right)$ and ${ }^{4} \mathrm{~T}_{1 \mathrm{~g}} \rightarrow{ }^{4} \mathrm{~T}_{2 \mathrm{~g}}(\mathrm{~F})\left(\mathbf{v}_{1}\right)$ respectively. (Cotton et al.,1999).

The magnetic moment values of $\mathrm{Ni}(\mathrm{II})$ complexes $(2,8,13,19)$ are in the range $2.94-3.13 \mathrm{BM}$ which are slightly higher than the spin only value of two unpaired electrons, indicating octahedral environment around $\mathrm{Ni}(\mathrm{II})$ ion. It is further confirmed by their electronic spectral bands observed at the regions 26315-24509 $\mathrm{cm}^{-1}, 17182-14686 \mathrm{~cm}^{-1}$ and $10845-9823 \mathrm{~cm}^{-1}$ assignable to ${ }^{3} \mathrm{~A}_{2 \mathrm{~g}}(\mathrm{~F}) \rightarrow{ }^{3} \mathrm{~T}_{1 \mathrm{~g}}(\mathrm{p}),{ }^{3} \mathrm{~A}_{2 \mathrm{~g}}(\mathrm{~F}) \rightarrow{ }^{3} \mathrm{~T}_{1 \mathrm{~g}}(\mathrm{~F}) \mathrm{and}^{3} \mathrm{~A}_{2 \mathrm{~g}}(\mathrm{~F}) \rightarrow{ }^{3} \mathrm{~T}_{2 \mathrm{~g}}(\mathrm{~F})$ transitions respectively (Cotton et al., 1999).

The electronic spectra of $\mathrm{Cu}(\mathrm{II})$ complexes $(3,9,20)$ contains a broad band at $13812-13405 \mathrm{~cm}^{-1}$. These bands are typical of $\mathrm{d}-\mathrm{d}$ band of Jahn-Teller distorted $\mathrm{Cu}(\mathrm{II})$ complexes in distorted octahedral geometry, and can be assigned to two or three of the transitions ${ }^{2} \mathrm{~B}_{1 \mathrm{~g}} \rightarrow{ }^{2} \mathrm{E}_{\mathrm{g}},{ }^{2} \mathrm{~B}_{1 \mathrm{~g}} \rightarrow{ }^{2} \mathrm{~B}_{2 \mathrm{~g}}$ and ${ }^{2} \mathrm{~B}_{1 \mathrm{~g}} \rightarrow{ }^{2} \mathrm{~A}_{1 \mathrm{~g}}$ (Singh, 2008). Magnetic moment of these complexes are in range 1.95-2.05 BM correspond to one unpaired electron and suggesting a monomeric octahedral geometry(Cotton et al., 1999 ). The relatively low magnetic moment of $1.46 \mathrm{BM}$ of the copper(II) complex (14) support the antiferromagnetic behavior of the proposed dimeric structure (Filipovic et al., 2009). The electronic spectrum of this complex exhibit a broad band at $9800-12195 \mathrm{~cm}^{-1}$ region. This band is characteristic of square pyramidal geometry (Mondal et al., 2013).

The diamagnetic $\mathrm{Zn}(\mathrm{II})$ complexes $(4,10,15,21)$. Thorium(IV) complexes $(5,17)$ and uranyl complexes $(6,11,16,22)$ show no prominent absorption in the visible region because of $\mathrm{d}^{10}$ and $\mathrm{f}^{0}$ configurations of $\mathrm{Zn}(\mathrm{II})$, $\mathrm{Th}(\mathrm{IV})$ and $\mathrm{U}(\mathrm{VI})$ ion respectively. 
Table 3: Electronic spectra and magnetic susceptibility data of the ligands and their complexes

\begin{tabular}{|c|c|l|}
\hline $\begin{array}{c}\text { Complex } \\
\text { No. }\end{array}$ & $\begin{array}{c}\boldsymbol{\mu}_{\text {eff }} \\
\text { B.M. }\end{array}$ & Eletronic Spectra $\mathbf{~ c m}^{-1}$ \\
\hline L1(AFPH) & ---- & 33112,29940 \\
\hline 1 & 4.96 & $32679,29585,28571,19230,16722,10526$ \\
\hline 2 & 3.13 & $30864,29239,27777,24509,14686,9823$ \\
\hline 3 & 1.95 & $31055,29498,27027,13405$ \\
\hline 4 & dia & $29761,28735,27397$ \\
\hline 5 & dia & $30674,29585,25773$ \\
\hline 6 & dia & $30487,29411,28409$ \\
\hline 7 & 4.87 & $32679,29585,26315,18248,16666,9803$ \\
\hline 8 & 3.10 & $31847,29411,28571,24630,16666,10845$ \\
\hline 9 & 1.98 & $32467,28735,27777,13812$ \\
\hline 10 & dia & $32894,29585,25252$ \\
\hline 11 & dia & $29411,28818,27932$ \\
\hline L2(TCPH) & ---- & 37593,32679 \\
\hline 12 & 4.81 & $32894,31250,27472,18181,14836,9803$ \\
\hline 13 & 2.98 & $34013,29585,27624,24630,15625,9852$ \\
\hline 14 & 1.46 & $30303,26385,24752,12195,9800$ \\
\hline 15 & dia & $31055,29411,27932$ \\
\hline 16 & dia & $31847,29585,25906$ \\
\hline 17 & dia & $32894,29411,28409$ \\
\hline 18 & 5.05 & $31250,29411,28901,18520,15230,10331$ \\
\hline 19 & 2.94 & $32467,29761,27472,26315,17182,9823$ \\
\hline 20 & 2.05 & $30120,29069,26455,13586$ \\
\hline 21 & dia & $31250,29585,25510$ \\
\hline 22 & dia & $32894,30303,27932$ \\
\hline
\end{tabular}

\section{Antibacterial activity}

The synthesized hydrazones AFPH and TCPH and some of their metal complexes $(3,4,14$, 21) were tested for their antimicrobial activity against selected bacteria, Gram-positive S.aureus and Gram-negative K.pneumoniae The results are presented in Table (4). It is clear that they have moderate antibacterial activity at the used concentration $(10 \mathrm{mg} / \mathrm{mL})$ except for the ligand AFPH and its $\mathrm{Zn}$ (II) complex (21), which were inactive against S.aureus. The higher activity of the metal complexes may be due to the presence of metal ions in the complexes.

Table 4: Antibacterial effects of the investigated compounds

\begin{tabular}{|c|c|c|c|}
\hline $\begin{array}{c}\text { Complex } \\
\text { No. }\end{array}$ & Compound & $\begin{array}{c}\text { Inhibition zone diameter } \\
*(\mathbf{m m}) \text { S.aureus }\end{array}$ & $\begin{array}{c}\text { Inhibition zone diameter } \\
*(\mathbf{m m}) \text { K.pneumoniae }\end{array}$ \\
\hline $\mathrm{L} 1$ & $\mathrm{AFPH}\left(\mathrm{C}_{12} \mathrm{H}_{11} \mathrm{~N}_{3} \mathrm{O}_{2}\right)$ & 6 & 8 \\
\hline $\mathrm{L} 2$ & $\mathrm{TCPH}\left(\mathrm{C}_{11} \mathrm{H}_{9} \mathrm{~N}_{3} \mathrm{OS}\right)$ & 8 & 7 \\
\hline 3 & {$\left[\mathrm{Cu}(\mathrm{AFPH}) \mathrm{H}_{2} \mathrm{OCl} \mathrm{Cl}_{2}\right]$} & 9 & 7 \\
\hline 4 & {$[\mathrm{Zn}(\mathrm{AFPH}-\mathrm{H}) \mathrm{Cl}]_{2}$} & 10 & 9 \\
\hline 14 & {$[\mathrm{Cu}(\mathrm{TCPH}-\mathrm{H}) \mathrm{Cl}]_{2}$} & 7 & 7 \\
\hline 21 & {$\left[\mathrm{Zn}(\mathrm{TCPH}-\mathrm{H})_{2}\right]$} & 6 & 15 \\
\hline & Amoxyline & 17 & 11 \\
\hline & Erthromaycine & 20 & \\
\hline
\end{tabular}

\section{CONCLUSION}

The present work describes the synthesis of 2-acetylfuran picolinoyl hydrazone (AFPH) and 2-thiophen carboxaldehyde picolinoyl hydrazone (TCPH) and the Co(II), Ni(II), Cu(II), Zn(II), $\mathrm{UO}_{2}$ (II) and Th(IV) complexes. The structural characterization of the synthesized compounds were 
made by using the elemental analyses, spectroscopic methods, magnetic and conductance studies . From the spectroscopic characterization, it is concluded that the heterocyclic hydrazones AFPH and $\mathrm{TCPH}$ act as neutral or monobasic tridentate ligands coordinating through carbonyl group oxgen, azomethine nitrogen and pyridine nitrogen atoms in the keto-form or enolate-form via deprotonation depending on the condition of the reaction and the type of metal salt used. Based on phesicochemical evidence, the proposed structures of the prepared complexes are exhibited in (Fig.1).

The antibacterial activity screening of the ligands and some of their complexes against two type of bacteria showed moderate antibacterial activity.
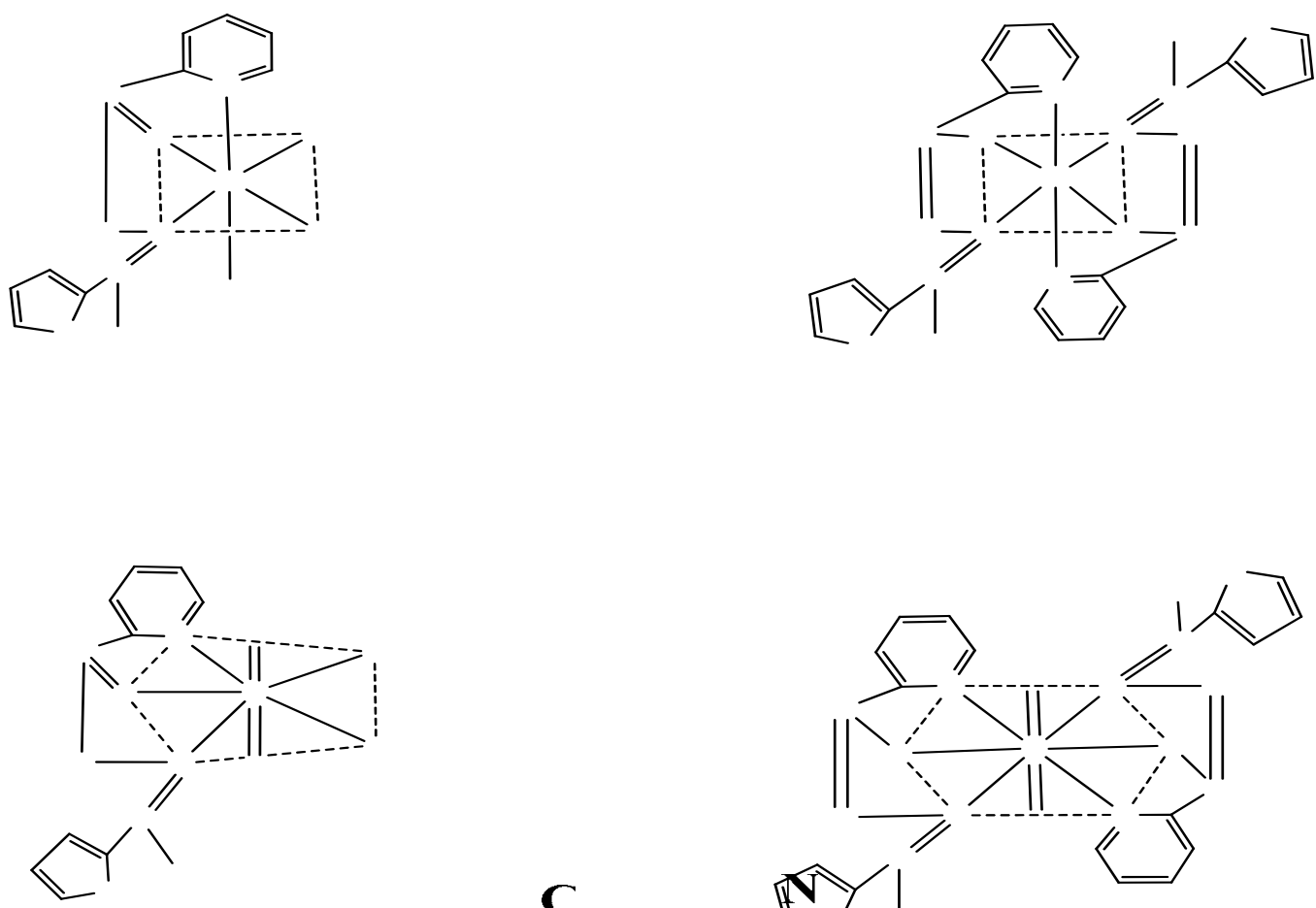

C

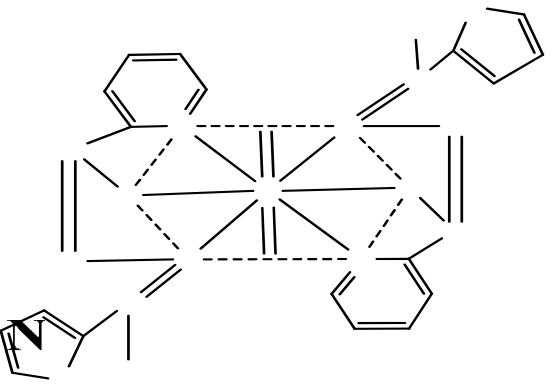

$\mathbf{O}$

Cl

$\mathbf{M}$

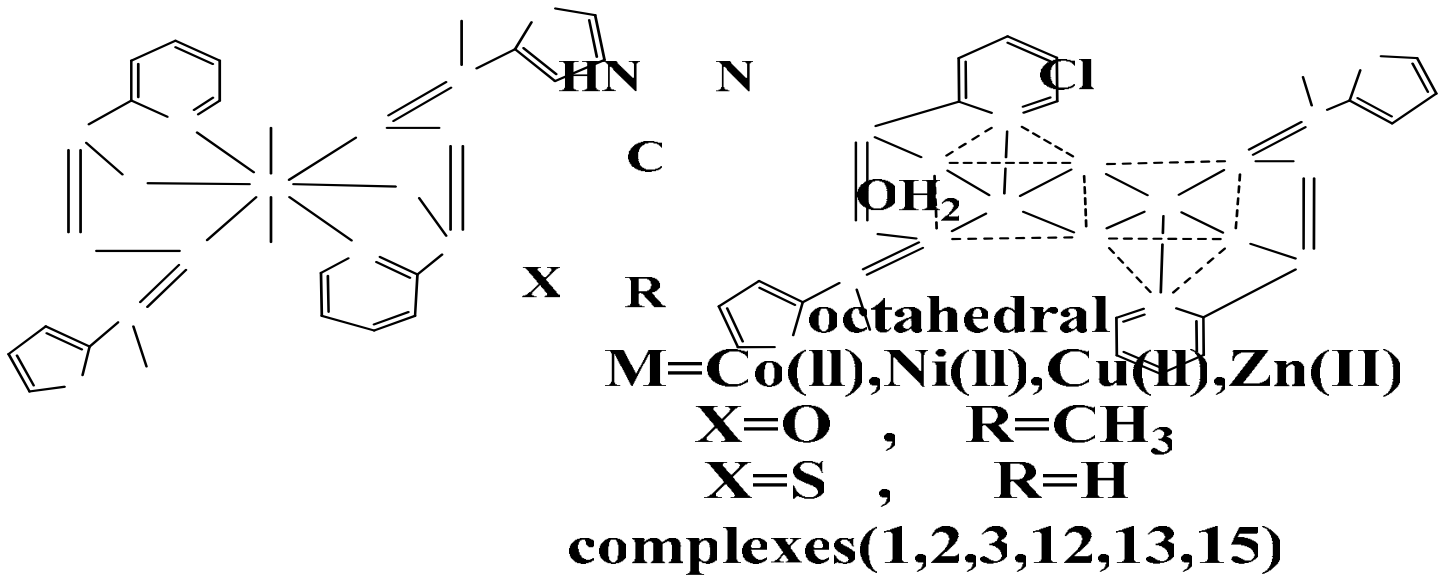

Fig. 1: Proposed structures for the prepared complexes.

C N O Cl




\section{REFERENCES}

Abd El-Motaleb, A.; Ramadan, M.; Issa, R.M. (2005). Synthesis, characterization and ascorbic acid oxidize mimetic catalytic activity of copper(II) picolyl hydrazone complexes. Trans. Met. Chem., 30, 471-480.

Abu Affan, Md.; Foo, S.W.; Jusoh, I.; Hanapi, S.; Tiekink, E.R.T. (2009). Synthesis Characterization and biological studies of organotin(IV) complexes with hydrazone ligand . Inorg. Chem. Acta, 362, 5031-5037.

Alagesan, M.; Bhuvanesh, N.S.P.; Dharmaraj, N. (2013). Potentially cyotoxic new Copper(II) hydrazone complexes: synthesis, crystal structure and biological properties. J. Chem. Soc., Dalton Trans., 42,7210 - 7223.

Al-Daher, A.G.M.; Mohammed, S.M. (2011). 2-Acetylpyridine acetyl hydrazone complexes with thorium (IV) and some divalent $3 \mathrm{~d}$ transition metal salts: synthesis, characterization and antibacterial activity. Proceeding 2nd Sci. Conf. Chem., Mosul, University, pp. 331-351.

Al-Daher, A.G.M.; Mustafa, S.M. (2013). Synthesis and characterization and antibacterial activity of 2-acetylpyridine-2-furoylhydrazone complexes with $\mathrm{UO}_{2}(\mathrm{II}), \mathrm{Th}(\mathrm{IV}), \mathrm{Co}(\mathrm{II}), \mathrm{Ni}(\mathrm{II})$, $\mathrm{Cu}(\mathrm{II})$, and $\mathrm{Zn}(\mathrm{II})$. Raf. J. Sci., accepted for publication.

Al-Daher, A.G.M.; Al-Qassar, I.A. (2011). Synthesis and characterization of $\mathrm{Co}(\mathrm{II}), \mathrm{Ni}(\mathrm{II}), \mathrm{Cu}(\mathrm{II})$, and Zn(II) complexes with 2-furaldehyde 2-thenoyl hydrazone. Raf. J. Sci., 22(4), 109-120.

Anwar, M.U.; Tandon, S.S.; Dawe, L.N ; Habib, F.; Murugesu, M.; Thompson, L.K. (2012). Lanthanide complexes of tritopic bis (hydrazone) ligands:single molecule magnet behaviour in a linear Dy(III) complex. Inorg. Chem., 51,1028-1034.

Cotton, F.A.; Wilkinson, G.; Murillo, C.A.; Bochmann, M. (1999). "Advanced Inorganic Chemistry". 6th edn., John Wiley and Sons, New York, pp. 810-842.

Despaigne, A.R.; Dasilva, J.G.; Docarmo, A.C.; Piro, O.E.; Castellano, E.E.; Beraldo, H. (2009). Copper(II) and zinc(II)complexes with 2-benzoyl pyridine-methyl hydrazone. J. Mol. Struct., 920, 97-102.

Filipovic, N.; Borrmann, H.; Todorovic, T.; Borna, M.; Spasojevic, V.; Saldic, D.; Novakodic, I. (2009). Copper(II) complexes of N-heteroatomic hydrazones: synthesis, X-ray structure, magnetic behaviour, and antibacterial activity. Inorg. Chim. Acta, 362, 1996-2000.

Gandi, J.B.; Kulkarni, N.D. (2001). Binuclear complexes with uranyl ions in non-equivalent coordination environments: synthesis and electrochemistry of the complexes with binucleating aroyl-hydrazones and 1,10-phenanthroline. Trans. Met. Chem., 26, 96-99.

Geary, W.J. (1971). The use of conductivity measurement in organic solvents for the characterization of coordination compounds, Coord. Chem. Rev., 7, 81-122.

Halli, M.B.; Malipatil, R.S. (2011). Synthesis, characterization and spectral studies of metal(II) complexes derived from benzofuran-2-carbohydrazide and 2-acetylthiophene Schiff's base. Der. Pharma. Chem., 3(4),146-157

Kethcum, P.A. (1988). "Microbiology: Concept and Applications". John Wiley and Sons, New York, $384 \mathrm{p}$.

Marczenko, Z.; Balcerzak, M. (2000). "Separation, Preconcentration and Spectrophotometry in Inorganic Analysis". Elsevier, pp. 425, 446.

Mondal, S.; Naskar, S.; Dey, A.K.; Sinn, E.; Eribal, C.; Herron, S.R.; Chattopadhyay, S. K. (2013). Mononuclear and binuclear $\mathrm{Cu}(\mathrm{II})$ complexes of some tridentate aroylhydrazone. $\mathrm{X}$-ray crystal structures of a mononuclear and a binuclear complex. Inorg. Chim . Acta, 398, 98-105 .

Monfared, H.H.; Falakin, H.; Bikas, R.; Mayer, P. (2013). Interamolecular hydrogen bond effect on keto-enolization of aroylhydrazone in copper(II) complexes. Inorg. Chem. Acta, 394, 526-534.

Perrin, D.D.; Armarego, W.L.; Perrin, D.R. (1980). "Purification of Laboratory Chemicals". 2nd ed., Pergamon press, Oxford, pp. 426, 445.

Rollas, L.; Kücükgüzel, S.G. (2007). Biological activities of hydrazone derivatives. Molecules, 12, 1910-1919. 
Saadeh, M.S.; Abu Shawish, H.M; Dalloul, H.M.; El-Halabi, N.M.; Daher, B.K. (2012). Lead(II) complexes with some SNO and ONO tridentate Schiff base ligands and their evaluation as lead sensor. Mater. Sci. Engn. C32,619-624.

Sharma, V.K.; Sarivastava, S.; Sarivastava, A. (2006). Synthesis and spectroscopic studies of novel mononuclear and binuclear ruthenium(III) complexes with bidentate and tridentate a cyclic hydrazine. J. Coord. Chem., 59(12),1321-1334.

Singh, V.P.; Singh, P. (2013). Synthesis, spectral characterization and thermal studies of Co(II), $\mathrm{Ni}(\mathrm{II}), \mathrm{Cu}(\mathrm{II})$, and $\mathrm{Zn}(\mathrm{II})$ complexes with 2-amino benzoic acid and 2-hydroxy benzoic acid thiophene 2-methylene hydrazide. J. Mol. Struct., 1035,363-370.

Singh, V.P. (2008). Synthesis, electronic and ESR spectral studies on copper (II) nitrate complexes with some acylhydrazines and hydrazones. Spectrochim. Acta. A71,17-72.

Singh, V.P; Singh, P.; Singh, A.K. (2011). Synthesis, structural and corrosion inhibition studies on cobalt(II), nickel(II) copper(II) and zinic(II) complexes with 2-acetylthiophene benzoylhydrazone. Inorg. Chem. Acta., 379,56-63.

Suvarapu, L.N.; Seo, Y.K.; Baek, S.O; Ammireddy, V.R. (2012). Review on analytical and biological application of hydrazones and their metal complexes. E-Journal Chem., 9(3) ,1288-1304.

Vogel, A.I. (1989). "Vogel's Textbook of Quantitative Analysis". 5th edn., Longoman Scientific and Technical, England, pp. 324-329,349.

Zareef, M.; Iqbal, R.; Zaidi, J.H.; Qadeer, G.; Wong, W.Y.; Akhtar, H. (2006). Crystal structure of picolinic acid hydrazide, $\mathrm{C}_{6} \mathrm{H}_{7} \mathrm{~N}_{3} \mathrm{O}$. Z. Kristallogr . NCS, 221, 307-308. 